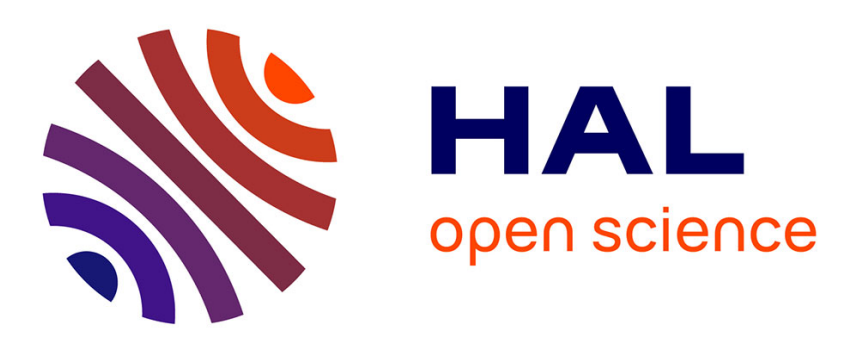

\title{
Reinforcing the origin of volcanic rocks from the Massif Central through the isotopic composition of lead and strontium
}

Philippe Négrel, C Guerrot, Emmanuelle Petelet-Giraud, Romain Millot

\section{- To cite this version:}

Philippe Négrel, C Guerrot, Emmanuelle Petelet-Giraud, Romain Millot. Reinforcing the origin of volcanic rocks from the Massif Central through the isotopic composition of lead and strontium. Journal of Geochemical Exploration, 2015, 153, pp.79-87. 10.1016/j.gexplo.2015.03.005 . insu-01138779

\section{HAL Id: insu-01138779 \\ https://hal-insu.archives-ouvertes.fr/insu-01138779}

Submitted on 3 Apr 2015

HAL is a multi-disciplinary open access archive for the deposit and dissemination of scientific research documents, whether they are published or not. The documents may come from teaching and research institutions in France or abroad, or from public or private research centers.
L'archive ouverte pluridisciplinaire HAL, est destinée au dépôt et à la diffusion de documents scientifiques de niveau recherche, publiés ou non, émanant des établissements d'enseignement et de recherche français ou étrangers, des laboratoires publics ou privés. 


\section{Accepted Manuscript}

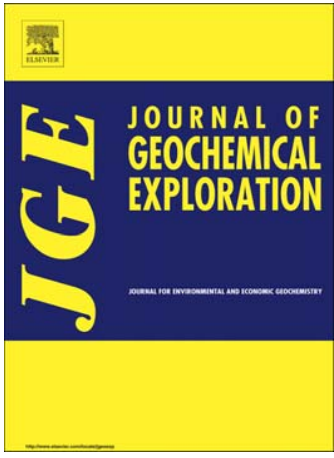

PII:

doi: 10.1016/j.gexplo.2015.03.005

Reference:

GEXPLO 5543

To appear in: Journal of Geochemical Exploration

Received date: 1 August 2014

Accepted date: 14 March 2015

Please cite this article as: Négrel, Ph., Guerrot, C., Petelet-Giraud, E., Millot, R., Reinforcing the origin of volcanic rocks from the Massif Central through the isotopic composition of lead and strontium, Journal of Geochemical Exploration (2015), doi: 10.1016/j.gexplo.2015.03.005

This is a PDF file of an unedited manuscript that has been accepted for publication. As a service to our customers we are providing this early version of the manuscript. The manuscript will undergo copyediting, typesetting, and review of the resulting proof before it is published in its final form. Please note that during the production process errors may be discovered which could affect the content, and all legal disclaimers that apply to the journal pertain. 


\title{
Reinforcing the origin of volcanic rocks from the Massif Central through the isotopic composition of lead and strontium
}

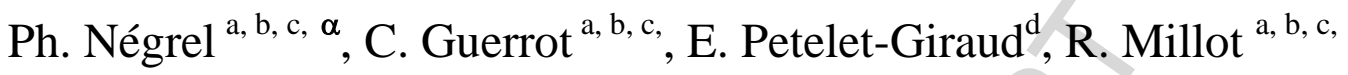 \\ a - BRGM, ISTO, UMR 7327, BP 36009, 45060 Orléans, France \\ b - CNRS/INSU, ISTO, UMR 7327, 45071 Orléans, France \\ c - Univ d'Orléans, ISTO, UMR 7327, 45071, Orléans, France \\ d - BRGM, Laboratory Division, Orléans, France
}

\begin{abstract}
:
The Massif Central in France hosts a large volume of Tertiary to Recent continental alkaline volcanism, with evidence of crustal contamination of the differentiated magmas. Detailed investigations on feldspathic basalts and basanite rocks from the Cantal volcano exposed in the Allanche basin by lead and strontium isotopes reveal i) the role of the mantle components Depleted Mantle (DM) and Low Velocity Component (LVC, corresponding to the European asthenospheric reservoir) end-members based on ${ }^{208} \mathrm{~Pb} /{ }^{204} \mathrm{~Pb}$ and ${ }^{206} \mathrm{~Pb} /{ }^{204} \mathrm{~Pb}$ isotopic ratios, and ii) show contamination by meta-igneous granulites from the lower crust when using ${ }^{207} \mathrm{~Pb} /{ }^{204} \mathrm{~Pb}$ vs. ${ }^{206} \mathrm{~Pb} /{ }^{204} \mathrm{~Pb}$ ratios, as only part of the samples plot along the Northern Hemisphere Reference Line (NHRL) mixing line between DM and HIMU (High U/Pb Mantle) end-members. Cross plotting of $\mathrm{Pb}$-Sr isotopes rules out recycled sediment and/or igneous granulite as potential crustal contaminant for the Cantal basalts, but suggests mixing between the low-velocity component LVC and EMI (Enriched Mantle I)-pelagic sediments. Replaced in the regional context of the Massif Central, we confirm the existence of several mantle sources and different crustal contaminations in the magmas of the Cantal volcano.
\end{abstract}

Keywords: lead isotopes, strontium isotopes, basalts, French Massif Central volcano

\footnotetext{
${ }^{\alpha}$ Corresponding author: 3 Avenue Claude Guillemin - BP6009 - 45060 Orléans cedex 1 France

Tél. : +33 (0) 238643969 Fax : +33-(0)2 38643711

e-mail : p.negrel@brgm.fr
} 


\section{Introduction}

During the Cenozoic, Africa and Europe converged, seafloor spreading took place in the Atlantic and, as a direct result of the convergence, numerous microplates in the Mediterranean area collided. This resulted in an intense igneous activity either related to subduction or to intra-plate geodynamics (Lustrino and Wilson, 2007). Consequently, Tertiary-Quaternary volcanic fields are found throughout Southern, Western and Central Europe (Wilson and Downes, 1992; Lustrino and Wilson, 2007), corresponding to the later phases of the Alpine orogeny and the Neogene collapse of the Mediterranean and Pannonian basins (Wilson and Downes, 1992). The main phases of volcanic activity occurred during the Miocene and Pliocene, with Pleistocene activity restricted only to specific areas. A possible geodynamic origin has been evoked for explaining diapiric mantle upwellings beneath the European lithosphere (Granet et al., 1995; Kolb et al., 2012). Hoernle et al. (1995) proved, using seismic tomography, the presence of a low S-wave-velocity anomaly, named Low Velocity Zone (LVC), extending from the eastern Atlantic to Central Europe. The LVC I interpreted as a common lithospheric mantle reservoir named European Asthenospheric Reservoir (EAR; Granet et al., 1995).

Here, we studied the central eastern part of the Cantal volcano, located in the French Massif Central. This area is one of the largest volcanic provinces in the country, whose volcanic forms include Strombolian cones aligned along fissures (Chaine des Puys), extensive basaltic plateaus (Aubrac and Devès), and two large central volcanoes (Cantal and Mont Dore). The Cantal volcano, equivalent in size of the Etna, was active between 13 and 3 million years ago. Numerous outcrops and the diversity of rocks emitted during its activity make it an ideal study site to investigate different magmatic processes affecting the composition of the volcanic rocks. Basalts from the Cantal stratovolcano are characterized by a significant change in their chemical composition over time, comparable to that observed for 
most intraplate basalts known on the Earth's surface. The volcanic rocks of the Massif Central consist of silica-saturated alkali rocks (olivine basalt, trachyandesite, trachyte, and rhyolite) and alkali-rich nepheline-normative rocks (basanite, tephrite and phonolite). Geochronological dating and lithostratigraphic studies linked the changes recorded in chemical composition to a change in their mantle source during spreading, which occurred however during a short geological period of 3 to 4 million years. Niobium $(\mathrm{Nb})$, thorium $(\mathrm{Th})$ and tantalum (Ta) and their respective ratios are key elements, and changes in $\mathrm{Nb}$ or $\mathrm{Th}$ contents reflect the gradual change in chemical composition between infra- and supra-Cantal basalts, i.e. changes in the composition of the underlying mantle during the construction of the volcano. This led to the development of several models of heterogeneous mantle source to explain the Massif Central basalts (Stettler and Allègre, 1979; Downes, 1987; Granet et al., 1995; Hoernle et al., 1995; Downes et al., 2003).

For several decades, the use of geochemistry comprising trace elements and/or radiogenic isotopes as natural tracers for investigating geological phenomena has been readily accepted by scientists scrutinizing processes that occur within the Earth (Allègre, 1982). In that way, numerous Tertiary-Quaternary volcanic fields have been investigated in Southern, Western and Central Europe (Downes, 1987; Witt-Eickschen et al., 2003; Dautria et al., 2010; Kolb et al., 2012; Lustrino et al., 2012; 2013; Bosch et al., 2014 and references therein). The present study investigated the $\mathrm{Pb}$ and $\mathrm{Sr}$ isotopes in rocks in the Allanche river drainage basin that drains part of the Massif Central (Fig. 1). In this study, we measured $\mathrm{Pb}$ and $\mathrm{Sr}$ isotopes to identify their sources in rock over the recent lava flows of the Cantal volcano and discuss the processes generating this large basalt area.

\section{Geology of the studied area}


The Allanche basin in the Massif Central covers $160 \mathrm{~km}^{2}$ with an elevation ranging from 1060 up to 1400 m a.s.l. (Fig. 1). The Allanche River flows through the lava plateau between the Cantal and Cézallier volcanoes (De Goër de Hervé, 1972; De Goër de Hervé and Tempier, 1988; Brousse and Lefevre, 1990). The main phase of volcanic activity within the Massif Central took place during the Late Miocene to Pliocene (Nehlig et al., 2001), dominated by eruptions from the Cantal (11-2.5 Ma) and Mont Dore (4-0.3 Ma), and by basaltic fissure eruptions in the Cézallier, Velay, Coirons, Aubrac and Devès areas. Volcanic activity resumed in some of the outlying areas of the massif (Causses, Sioule and Limagne), the youngest volcanic activity occurring in the Vivarais (12,000 yrs BP) and the Chaine des Puys (4,000 yrs BP). More specifically, the Cantal and Cézallier volcanoes were marked by two main periods of basalt emission: the Infracantalian (13-9.5 Ma) and the Supracantalian periods (6-3 Ma). The basalt composition ranges from alkali basalt to basanite, explained by variations in the degree of partial melting of a common mantle source (Granet et al., 1995; Pilet et al., 2005).

The Allanche basin is underlain by alkaline basalt from three volcanic cycles: 8 to 5.4 Ma (Late Miocene), 5.4 to $3 \mathrm{Ma}$ (Pliocene) and 240,000 to 6,000 yrs BP. The rocks in this basin comprise feldspathic basalt and basanite (De Goër de Hervé, 1972; De Goër de Hervé and Tempier, 1988; Brousse and Lefevre, 1990; Nehlig et al., 2001). Feldspathic basalt has an $\mathrm{SiO}_{2}$ content close to $46-49 \%$ and less than $5 \%$ of $\mathrm{Na}_{2} \mathrm{O}+\mathrm{K}_{2} \mathrm{O}$. The main mineral in these basalts is plagioclase (An 55-70) with normative nepheline, hypersthene and olivine. Basanite (nepheline- or leucite basalt) has a $\mathrm{SiO}_{2}$ content of $41-45 \%$, low $\mathrm{Na}_{2} \mathrm{O}+\mathrm{K}_{2} \mathrm{O}(<5 \%)$, and modal or normative nepheline or leucite. The groundmass includes clinopyroxene and plagioclase (An 50-60).

\section{Sampling and Methods}


Figure 1a shows the general location of the volcanic areas in the Massif Central, Figure 1b showing the basin configuration and the bedrock sampling points, corresponding lithologies are illustrated in Figure 1c. Sampling was primarily guided by the presence of outcrops and secondly by their accessibility along the river and the possibility to collect fresh unaltered rock. Three types of rocks were collected, feldspathic basalt, basanite (nepheline-leucite) and basanite (nepheline) according to the classification given by De Goër De Hervé and Tempier (1988).

The collected samples (several $\mathrm{kg}$ ) were powdered-quartered prior to analysis. $\mathrm{Pb}$ isotopes were determined with a Thermo-Finnigan MC-ICPMS Neptune. For isotopic measurements, the powdered sample was transferred into a Teflon container and subjected to standard dissolution procedures in hot $\mathrm{HCl}, \mathrm{HNO}_{3}, \mathrm{HF}$ and $\mathrm{HClO}_{4}$. Chemical separation of $\mathrm{Pb}$ was done with an ion-exchange column and blanks for this procedure were lower than $100 \mathrm{pg}$ and are negligible relative to the amount of sample analyzed. After chemical separation, the solutions were adjusted to a $\mathrm{Pb}$ concentration of $50 \mu \mathrm{g} \mathrm{\textrm {L } ^ { - 1 }}$ and, similarly, a standard solution (NBS 981) was also adjusted at $50 \mu \mathrm{g} \mathrm{L}^{-1}$. Around $25 \mathrm{ng} \mathrm{Tl}$ was added to the solution. A bracketing procedure with the sequence blank - standard or sample - cleaning solution was used for controlling the potential mass-bias instability of the instrument. The ${ }^{204} \mathrm{Hg}$ contribution to the 204 peak was corrected using ${ }^{202} \mathrm{Hg}$ and applying a ${ }^{202} \mathrm{Hg} /{ }^{204} \mathrm{Hg}$ ratio of 4.35. The measured ratios were normalized with ${ }^{205} \mathrm{Tl} /{ }^{203} \mathrm{Tl}$ for correcting mass fractionation (exponential law). This procedure allowed isotopic determination with an external precision $(2 \sigma)$ of $0.1 \%$ for ${ }^{206} \mathrm{~Pb} /{ }^{204} \mathrm{~Pb},{ }^{207} \mathrm{~Pb} /{ }^{204} \mathrm{~Pb}$ and ${ }^{208} \mathrm{~Pb} /{ }^{204} \mathrm{~Pb}$ following the method developed by our group and reported in Cocherie and Robert (2007).

Chemical purification of Sr was done with an ion-exchange column ( $\mathrm{Sr}-\mathrm{Spec})$ before mass analysis according to Pin and Bassin, 1992) with a total blank of less than $1 \mathrm{ng}$ for the entire chemical procedure. After chemical separation, Sr was analyzed with a Finnigan 
MAT262 thermal ionization mass spectrometer. The ${ }^{87} \mathrm{Sr} /{ }^{86} \mathrm{Sr}$ ratios were normalized to an ${ }^{86} \mathrm{Sr} /{ }^{88} \mathrm{Sr}$ ratio of 0.1194 and then adjusted to the NBS987 standard value of 0.710240 . An average internal precision of $\pm 10 \mathrm{ppm}\left(2 \sigma_{\mathrm{m}}\right)$ was obtained and the reproducibility of the ${ }^{87} \mathrm{Sr} /{ }^{86} \mathrm{Sr}$ ratio measurements was tested by repeated analyses of the NBS987 standard, with a mean value of $0.710246 \pm 0.000012(2 \sigma ; \mathrm{n}=28)$.

\section{Results}

Lead and strontium isotope results obtained for seven rocks are given in Table 1. The major oxide and trace element data from Négrel and Deschamps (1996) are also reported. The $\mathrm{SiO}_{2}$ and $\mathrm{K}_{2} \mathrm{O}$ variations of the seven basaltic rocks from the basin can be evaluated through mean values and standard deviations (Table 1 ). $\mathrm{SiO}_{2}$ and $\mathrm{K}_{2} \mathrm{O}$ contents average $46.8 \% \pm 3.1$ and $2.0 \% \pm 0.5$, respectively. The ${ }^{206} \mathrm{~Pb} /{ }^{204} \mathrm{~Pb}$ ratios range between 18.9 and 19.5 in the bedrock (Table 1) and the seven analyzed bedrock samples show ${ }^{87} \mathrm{Sr} /{ }^{86} \mathrm{Sr}$ ratios in the range between 0.70357 and 0.70378 (Table 1). Variations between the lead-isotope ratios $\left({ }^{206} \mathrm{~Pb} /{ }^{204} \mathrm{~Pb}\right.$, ${ }^{207} \mathrm{~Pb} /{ }^{204} \mathrm{~Pb}$ and ${ }^{208} \mathrm{~Pb} /{ }^{204} \mathrm{~Pb}$ ) are illustrated in Figure 2. Variations between the ${ }^{87} \mathrm{Sr} /{ }^{86} \mathrm{Sr}$ ratios are illustrated in Figure 3 and plotted against the 1/Sr and $\mathrm{Rb} / \mathrm{Sr}$ ratios. In these figures, the results of the lead and strontium isotopes obtained on the Allanche basin have been replaced in the large frame of the volcanic rocks from the Massif Central using data from the literature. Compared with ratios of other volcanic rocks from the Massif Central, our data lie in the range of published $\mathrm{Pb}$ and $\mathrm{Sr}$ isotope ratios. The samples from the Allanche basin display the highest $\mathrm{Pb}$ contents observed in the volcanic rocks of the Massif Central.

\section{Discussion}

\subsection{Mantle source heterogeneity revealed by the Massif Central volcanism}

Several mantle sources have been identified worldwide including depleted mantle (DM) and high $\mathrm{U} / \mathrm{Pb}$ mantle (HIMU). The mantle is encompassed by just four components, or end 
members: depleted MORB mantle (DM), HIMU (high $\mu$, or high ${ }^{238} \mathrm{U} /{ }^{204} \mathrm{~Pb}$ ), EM-I and EM-II (enriched mantle EM-type ocean-island basalt 'I' and 'II', respectively), as summarized by Zindler and Hart (1986); Hart (1988) and review in Stracke (2012). Considering the evolution of the oceanic lithosphere, Pilet et al. (2005) discussed that EM-I represents the final stage of metasomatic melt evolution, EM-II corresponding to the extreme fractionation stage for trace elements by metasomatic processes, while Jackson and Dasgupta (2008) argued for the presence of recycled sediment or continental crust, or metasomatism by low degree melts and/or fluids. Recently, Willbold and Stracke (2010) discussed the recycling of upper and lower continental crust, and Wilson and Downes (1992) and Pilet et al. (2005) considered all end-members as influencing the volcanic rocks from the Massif Central. The correlation between the ${ }^{207} \mathrm{~Pb} /{ }^{204} \mathrm{~Pb} v$ s. $1 / \mathrm{Pb}$ ratios shown in Figure 2 is $\mathrm{R}^{2}=0.31$, and $\mathrm{R}^{2}=0.77$ between the ${ }^{208} \mathrm{~Pb} /{ }^{204} \mathrm{~Pb}$ and ${ }^{206} \mathrm{~Pb} /{ }^{204} \mathrm{~Pb} v s .1 / \mathrm{Pb}$ ratios. These relationships reflect the existence of two endmembers with a lowering of the lead isotope ratio as the lead content increases, indicating at least two sources for the volcanic rocks. A similar set of relationships can be observed in volcanic rocks from the Chaine des Puys (Hamelin et al., 2009). Figure 4 shows the variation of the ${ }^{208} \mathrm{~Pb} /{ }^{204} \mathrm{~Pb}$ vs. ${ }^{206} \mathrm{~Pb} /{ }^{204} \mathrm{~Pb}$ ratios for the Allanche samples and other volcanic rocks from the Massif Central and the different end-members forming the mantle. These are HIMU and DM, and EM-I and -II, the linear mixing line defined as the Northern Hemisphere Reference Line is also represented (NHRL, Hart, 1984). All data in Figure 4 plot close to the NHRL, diverging only by lower ${ }^{206} \mathrm{~Pb} /{ }^{204} \mathrm{~Pb}$ ratios through the EM-I and II influence. Along the NHRL, the role of the low-velocity component (LVC; Hoernle et al., 1995) in the origin of the volcanic rocks is obvious. Isotopic characterization has allowed defining a common end-member in the mix along the NHRL line in Europe, the Mediterranean and the western Canaries. Several authors have summarized lead isotope ratios for this component, assigning highly radiogenic values to the LVC which was explained by Granet et al. (1995) as being of 
asthenospheric origin (EAR) and interpreted as an upwelling in the upper mantle by Hoernle et al. (1995).

Thus, regarding ${ }^{208} \mathrm{~Pb} /{ }^{204} \mathrm{~Pb}$ vs. ${ }^{206} \mathrm{~Pb} /{ }^{204} \mathrm{~Pb}$ ratios, the volcanic rocks of the Massif Central are mainly the result of mixing between the DM and LVC components. However, the investigated samples from the Allanche area show a dominance of the DM over LVC. Such an influence was previously stated by Downes et al. (2003) regarding the mantle components in the Massif Central and by Lenoir et al. (2000) studying the evolution of the upper mantle below the Massif Central through the Forez volcanism (Fig. 1). As for Figure 4, the ${ }^{207} \mathrm{~Pb} /{ }^{204} \mathrm{~Pb} v s .{ }^{206} \mathrm{~Pb} /{ }^{204} \mathrm{~Pb}$ ratios of the volcanic rocks in the Massif Central partly plot along the NHRL mixing line together with the LVC component that also plots along the NHRL line (Figure 5). This first approach shows the role of the major mantle components in the origin of volcanic rocks of the Massif Central. The rest of the samples being shifted from the NHRL line are related to another process like fractional crystallization and assimilation.

\subsection{Fractional crystallization and assimilation documented by the Massif Central volcanism}

The relationships between $\mathrm{SiO}_{2}$ and $\mathrm{K}_{2} \mathrm{O}$ contents in the samples from the Allanche area within the context of the Massif Central volcanism are illustrated in Figure 6. The samples values fall between the fields of basanite and feldspathic basalt and are coherent with literature data (De Goër de Hervé and Tempier, 1988; Nehlig et al., 2001), whereas enrichment in alkalis reflects the different series in the volcanic rocks from the Massif Central (Fig. 1, Chauvel and Jahn, 1984; Downes, 1987; 1993; Wilson and Downes, 1992; Lenoir et al., 2000; Dautria et al., 2004; Pilet et al., 2005; Hamelin et al., 2009). Fractional crystallization and assimilation were shown to be an important phenomenon in the Massif Central volcanoes, particularly in the most differentiated trachyte and phonolite (Chauvel and Jahn, 1984; Downes, 1987). For the less evolved basanite and alkali basalt, fractional 
crystallization and assimilation cannot be ruled out (Downes, 1987), as can be seen in the concentration of selected incompatible elements or in the consistency of ratios like the $\mathrm{Rb} / \mathrm{Sr}$ ratio (Chauvel and Jahn, 1984).

The Tertiary volcanic rocks from the Massif Central have been widely investigated by means of the $\mathrm{Sr}-\mathrm{Nd}-\mathrm{Pb}$ isotope triptych. Investigations using Sr isotopes (Stettler and Allègre, 1979), and Sr- Nd isotopes (Downes, 1984; Chauvel and Jahn, 1984; Briot, 1990; Briot et al., 1991; Lenoir et al., 2000; Dautria et al., 2004) indicate that the calc-alkaline and alkali magmas originated from similar magmatic sources in the lithospheric mantle and assimilated similar rocks of the continental crust. These studies showed that the rocks contain xenoliths derived from the mantle (peridotite) and the continental crust (granulite, granite gneiss, and granite). According to Stettler and Allègre (1979), the evolution of $\mathrm{Rb}$ and $\mathrm{Sr}$ may be interpreted in two different ways depending on whether fractional crystallization or assimilation is the predominant differentiation process. The evolution of $\mathrm{Rb} v s$. Sr content in our data and those existing for the Massif Central, illustrated in Figure 7 (Stettler and Allègre, 1979; Condomines et al., 1982; Chauvel and Jahn, 1984; Downes, 1984; Dautria et al., 2004; Pilet et al., 2005; Hamelin et al., 2009) show two trends. The first trend relates basalt to andesite, in which $\mathrm{Rb}$ and $\mathrm{Sr}$ are positively correlated and in that way the trend reflects the differentiation of the basaltic melt. The second trend relates the first trend to rhyolite, where high $\mathrm{Rb}$ are associated with low $\mathrm{Sr}$, and reflects evolved fractional crystallization. The ${ }^{87} \mathrm{Sr} /{ }^{86} \mathrm{Sr}$ vs. $1 / \mathrm{Sr}$ ratios, illustrated in Figure $3 \mathrm{a}$ and $\mathrm{b}$, show no clear relationship $\left(\mathrm{R}^{2}=0.20\right.$, $\mathrm{n}=7$ ) precluding simple linear mixing as suggested by Briot (1990) and indicating that the magma reservoir was not isotopically homogeneous. A significant regression can be seen when considering the relationship between the ${ }^{87} \mathrm{Sr} /{ }^{86} \mathrm{Sr} v s . \mathrm{Rb} / \mathrm{Sr}$ ratios (Fig. $3 \mathrm{c}$ and d) in our samples, the equation for which is ${ }^{87} \mathrm{Sr} /{ }^{86} \mathrm{Sr}=-0.00927 \times \mathrm{Rb} / \mathrm{Sr}+0.70423\left(\mathrm{R}^{2}=0.57, \mathrm{n}=7\right)$. However, this relationship cannot be applied to the entire Massif Central (Stettler and Allègre, 
1979; Condomines et al., 1982; Chauvel and Jahn, 1984; Downes, 1984; Dautria et al., 2004; Pilet et al., 2005; Hamelin et al., 2009). This suggests that contamination by the crust component does not have the same $\mathrm{Rb} / \mathrm{Sr}$ ratio over the area or that this relationship corresponds to a different behavior of $\mathrm{Sr}-\mathrm{Rb}$ during basalt crystallization. With increasing $\mathrm{SiO}_{2}$, the differentiated samples display increasing ${ }^{87} \mathrm{Sr} /{ }^{86} \mathrm{Sr}$ shown in Figure 8 as previously found by Kolb et al. (2012) in Germany (e.g. the Siebengebirge Volcanic Field that forms part of the Central European Volcanic Province). The data of Kolb et al. (2012) on Figure 8 fit well our data. Such relationships indicate an open-system behavior during differentiation associated with crustal assimilation. This field fits well our data and those from the rest of the Massif Central volcanism. The defined trend seems to indicate that regional lower crust, represented by granulite xenoliths, might be a potential contaminant candidate.

In the Sr-Nd diagram, the mixing plots indicate that saturated magmas assimilated up to $40 \%$ of deep-crustal granulite, whereas alkali-rich magmas assimilated less than $20 \%$ (Faure, 2001). Similar to the Nd-Sr data, the history recorded in the lead-isotope compositions of the Massif Central reveals a complex sequence of events. The ${ }^{207} \mathrm{~Pb} /{ }^{204} \mathrm{~Pb} v s .{ }^{206} \mathrm{~Pb} /{ }^{204} \mathrm{~Pb}$ plot (Fig. 5) shows that the volcanic rocks in the Massif Central partly plot along the NHRL mixing line. Most of the reported volcanic bedrock data in the Massif Central plot away from the NHRL, again interpreted in terms of component mixing between different end-members. This reinforces the arguments developed first by Downes (1987) and Downes et al. (1991), who suggested that crustal contamination occurred in the volcanic rocks from the Massif Central. Studying the Chaine des Puys volcanoes in the northern part of the Massif Central, Hamelin et al. (2009) investigated such possible contaminating crustal components. One possibility they discuss is the upper continental crust (Variscan granitoids), but their $\mathrm{Pb}$ isotopic ratios seem to be too low (Downes et al., 1997). Another contaminant may be the lower crust, through meta-igneous and meta-sedimentary granulite xenoliths (Downes, 1993; 
Downes et al., 1990). Based on Pb isotopes, Hamelin et al. (2009) mentioned a metasedimentary granulite contamination in the Chaine des Puys volcanoes.

However, the samples from the Allanche basin clearly diverge from the Chaine des Puys line as defined by Hamelin et al. (2009), whereby a predominant feature is a larger variation of the ${ }^{206} \mathrm{~Pb} /{ }^{204} \mathrm{~Pb}$ ratio than the ${ }^{207} \mathrm{~Pb} /{ }^{204} \mathrm{~Pb}$ ratio. The data from the Allanche basin were regressed in Figure 5 to give a least-square line describing the general trend between the two lead-isotope ratios. The resulting trend, with a $\mathrm{R}^{2} \sim 0.51(\mathrm{n}=7)$ and a slope of 0.03 , agrees with some of the data from the Cantal volcano included in the trend and reported by Downes (1987) and Wilson and Downes (1992). As many authors interpret the scatter of lead-isotope values in the Massif Central as being a sign of crustal contamination, the coherent variations of $\mathrm{Pb}$-isotope compositions in Figure 5 clearly agree with the assimilation of lower crust as a main contaminant. Contrary to the Chaine des Puys volcanoes, where a meta-sedimentary granulite contamination is suspected by Hamelin et al. (2009), the best candidate for a contamination end-member of the Cantal volcanoes is meta-igneous granulite (Fig. 5). Therefore, the presence of such volcanic rocks in the Allanche catchment is consistent with mixing between two components: one component having LVC isotope characteristics, and a second component having isotope compositions similar to meta-igneous granulite as discussed by Downes et al. (1991). The ${ }^{207} \mathrm{~Pb} /{ }^{204} \mathrm{~Pb}$ and ${ }^{206} \mathrm{~Pb} /{ }^{204} \mathrm{~Pb}$ mixing line between these two components (Fig. 5) shows that a mixture between these end-members explains the scattering of $\mathrm{Pb}$-isotope values in the volcanic rocks of the Allanche basin, which agrees with the resulting trend observed in our data. Comparing to other data from the Cantal (Downes, 1987; Wilson and Downes, 1992), our data show a higher degree of contamination. 
5.3 Combining lead and strontium isotope data: a better constraint of the crustal contamination of volcanic rocks from the Massif Central and evaluation of their potential mantle sources

Figure 9 shows the variation of the ${ }^{87} \mathrm{Sr} /{ }^{86} \mathrm{Sr} v s .{ }^{206} \mathrm{~Pb} /{ }^{204} \mathrm{~Pb}$ ratios in bedrock data from the Massif Central (Downes, 1987; Wilson and Downes, 1992; Lenoir et al., 2000; Pilet et al., 2005; Hamelin et al., 2009; this study) with the different end-members. The Sr isotopes reinforce the lead data and their contribution to our knowledge of the volcano and its formation processes.

The isotopic data reveal two evolutionary trends, characterized by samples from the Cantal (Pilet et al., 2005 and our data) and the Chaine des Puys (Hamelin et al., 2009). Samples from Pilet et al. (2005) for the Cantal are close to the LVC component (lowest ${ }^{87} \mathrm{Sr} /{ }^{86} \mathrm{Sr}$ ratio and the highest ${ }^{206} \mathrm{~Pb} /{ }^{204} \mathrm{~Pb}$ ratio) representing the EAR. On the contrary, samples from Hamelin et al. (2009) have the highest ${ }^{87} \mathrm{Sr} /{ }^{86} \mathrm{Sr}$ ratio and intermediate ${ }^{206} \mathrm{~Pb} /{ }^{204} \mathrm{~Pb}$ ratio. Samples from this study are characterized by a rather low ${ }^{87} \mathrm{Sr} /{ }^{86} \mathrm{Sr}$ (close to that of Pilet et al., 2005) and the lowest ${ }^{206} \mathrm{~Pb} /{ }^{204} \mathrm{~Pb}$ ratio. The roughly triangular positions of isotopic data in Fig. 9 seem to support a three-component model. When looking at the isotopic character of the rocks in relation to the mantle end-member components, the involvement of LVC and EM (I and II) can be inferred. Combining $\mathrm{Pb}$ and $\mathrm{Sr}$ isotopic data for volcanic rocks from the eastern (Forez, Lenoir et al., 2000) and western volcanic provinces (Cantal, Chaine des Puys) reveals common isotopic values similar to those of LVC, followed by a contrasting divergence. The Cantal and Forez show isotopic signatures more similar to that of enriched mantle EM-I, while the Chaine des Puys is more similar to the EM-II component.

Thus, the $\mathrm{Sr}-\mathrm{Pb}$ isotope diagram reveals for the Cantal basalts a variation between EMI and LVC compositions, while basalts from other areas of the Massif Central vary between the EMII and the LVC compositions. This can be modeled by calculating mixing 
curves between $\mathrm{Sr}$ and $\mathrm{Pb}$ isotopes, as it was done for mantle-crust mix (Allègre, 2008). In order to illustrate the mixing in Figure 9, we used the characteristics of EMI and EMII that have been associated with pelagic and terrigenous sediments, recycled with, or without, oceanic crust (Allègre, 1987). The $\mathrm{Sr}-\mathrm{Pb}$ data for the mixing calculation are from Weaver (1991) for the pelagic and terrigenous sediments $\left({ }^{87} \mathrm{Sr} /{ }^{86} \mathrm{Sr}=0.712\right.$; $\mathrm{Sr}$ content $=1500 \mu \mathrm{g} \mathrm{g}{ }^{-1}$ ${ }^{206} \mathrm{~Pb} /{ }^{204} \mathrm{~Pb}=15.91 ; \mathrm{Pb}$ content $=50 \mu \mathrm{g} \mathrm{g}^{-1}$ ) and Hoernle et al. (1995) for the LVC component $\left({ }^{87} \mathrm{Sr} /{ }^{86} \mathrm{Sr}=0.7032 ; \mathrm{Sr}\right.$ content $=600 \mu \mathrm{g} \mathrm{g}{ }^{-1}{ }^{206} \mathrm{~Pb} /{ }^{204} \mathrm{~Pb}=20 ; \mathrm{Pb}$ content $\left.=3 \mu \mathrm{g} \mathrm{g}^{-1}\right)$.

A LVC-EMI-pelagic sediments mixing curve (Fig. 9) explains all data from the Cantal, i.e. data from Pilet et al. (2005) and this study, though our data are the most EMIcontaminated found in the Cantal. This mixing curve also fits the data from the eastern volcanic provinces of the Forez (Lenoir et al., 2000). However, sedimentary and/or igneous granulite as crustal contaminants for the Cantal basalts (Downes, 1987) do not fit the data (Fig. 9). On the other hand testing such mixing between LVC and the different crustal contaminants as done in previous studies, (i.e. granulite, terrigenous sediments, crust) explains well the Chaine des Puys rocks (Hamelin et al., 2009; Fig. 9). This testifies the existence of a ca. 100-km-scale heterogeneity within the magmatic sources of the western and eastern Massif Central volcanism. Consequently, the Cantal basalts cannot be considered as homogeneous with respect to their $\mathrm{Sr}$ and $\mathrm{Pb}$ isotopic compositions, demonstrating the involvement of variable sediment contamination of their mantle sources. According to the mixing curve in Fig. 9, the degree of contamination of Cantal basalts fluctuates between 0.3 and $1.5 \%$.

\section{Conclusions}

We present lead and strontium-isotopic ratios together with major- and trace elements in the bedrock of a small mono-lithologic basalt basin (Allanche River, $160 \mathrm{~km}^{2}$ ) belonging to the 
Cantal volcano in the French Massif Central. Results are discussed and compared to regional bedrock samples of the volcanic Massif Central province, which resulted from a complex history and multiple reservoir sources and mixing. Part of the lead-isotope data from the Allanche basin agree with literature data of Massif Central volcanic rocks that resulted from of a mixing between the well-defined mantle sources: (DM) and (LVC) end-members. The latter is of asthenospheric origin and corresponds to the European asthenospheric reservoir (EAR). The bedrock samples analyzed during this work show a strong influence of the DM component based on ${ }^{208} \mathrm{~Pb} /{ }^{204} \mathrm{~Pb}$ and ${ }^{206} \mathrm{~Pb} /{ }^{204} \mathrm{~Pb}$ isotopic ratios. Using ${ }^{207} \mathrm{~Pb} /{ }^{204} \mathrm{~Pb}$ vs. ${ }^{206} \mathrm{~Pb} /{ }^{204} \mathrm{~Pb}$, the Massif Central rocks only partly plot along the NHRL mixing line between the mantle components (DM and HIMU end-members). Most of the regional volcanic rocks diverge from the NHRL mixing line, implying another process like fractional crystallization and assimilation (e.g. contamination) by another reservoir. This is similar to the Chaine des Puys volcanoes that were contaminated by meta-sedimentary granulite from the lower crust (Hamelin et al., 2009). Data from the Allanche bedrock clearly define a different trend from that of the Chaine des Puys, implying another contamination source; they are consistent with previous results on the Cantal volcano and plead in favor of binary mixing between the LVC component and meta-igneous granulite from the lower crust. Finally, data from the Allanche catchment also suggest a higher degree of contamination by meta-igneous granulite than previously found by Wilson and Downes (1992) on the Cantal volcano.

Trends of the ${ }^{87} \mathrm{Sr} /{ }^{86} \mathrm{Sr}$ and ${ }^{206} \mathrm{~Pb} /{ }^{204} \mathrm{~Pb}$ isotopic ratios suggest mixing between the lowvelocity component LVC and EMI-pelagic sediments end-members. The mixing curve calculated between these two components fits all data from the Cantal volcano and the data from the east volcanic provinces of the Forez. Cross plot $\mathrm{Pb}-\mathrm{Sr}$ isotopes ruling out recycled sediment and/or igneous granulite as crustal contaminant for the Cantal basalts. This study 
thus provides additional insight into the volcanic history of the Massif Central and illustrates the lead-strontium source fingerprinting at regional scale $\left(160 \mathrm{~km}^{2}\right)$.

\section{Acknowledgements}

This work was financially supported by the BRGM Research Division programs. It benefited from the collaboration of the BRGM Isotope laboratories, and M. Robert and A.M. Gallas are thanked for their help. We are grateful to Dr. H.M. Kluijver for proofreading and editing the English text. The authors are grateful to the anonymous reviewers for thoughtful revisions of the manuscript and constructive comments.

\section{References}

Allègre, C.J. 1982. Chemical geodynamics. Tectonophysics 81, 109-132.

Allègre, C.J. 1987. Isotope geodynamics. Earth Planet. Sci. Lett. 86, 175-203.

Allègre, C.J. 2008. Isotope Geology. Cambridge University Press, 512p.

Bosch, D., Maury, R.C., El Azzouzi, M., Bollinger, C., Bellon, H., Verdoux, P. 2014. Lithospheric origin for Neogene-Quaternary Middle Atlas lavas (Morocco): Clues from trace elements and $\mathrm{Sr}-\mathrm{Nd}-\mathrm{Pb}-\mathrm{Hf}$ isotopes. Lithos 205, 247-265.

Briot, D. 1990. Magma mixing versus xenocryst assimilation: The genesis of trachyandesites in Sancy volcano, Massif Central, France. Lithos 25, 227-241.

Briot, D., Cantagrel, J.M., Dupuy, C., Harmon, R.S. 1991. Geochemical evolution in crustal magma reservoirs: Trace-element and Sr-Nd-O isotopic variations in two continental intraplate series at Monts Dore, Massif Central, France. Chem. Geol. 89, 281-303.

Brousse, R. Lefevre, C. 1990. Le volcanisme en France et en Europe limitrophe. Masson ed., $262 \mathrm{p}$. 
Chauvel, C., Jahn, B.M. 1984. Nd-Sr isotope and REE geochemistry of alkali basalts from the Massif Central, France. Geochim. Cosmochim. Acta 48, 93-110.

Cocherie, A., Robert, M. 2007. Direct measurement of lead isotope ratios in low concentration environmental samples by MC-ICP-MS and multi-ion counting. Chem. Geol. 243, 90-104.

Condomines, M., Morand., P, Camus, G., Duthou, L. 1982. Chronological and Geochemical Study of Lavas from the Chaine des Puys, Massif Central, France: Evidence for Crustal Contamination. Contrib Mineral Petrol 81, 296-303.

Dautria, J.M., Liotard, J.M., Briot, D. 2004. Particularités de la contamination crustale des phonolites : exemple du Velay oriental (Massif Central). C.R. Geoscience 336, 971-981.

Dautria, J.M., Liotard, J.M., Bosch, D., Alard, O. 2010. 160 Ma of sporadic basaltic activity on the Languedoc volcanic line (Southern France): A peculiar case of lithosphereasthenosphere interplay Lithos 120, 202-222.

De Goër De Hervé, A. 1972. La planèze de Saint-Flour, structure et stratigraphie; vol.I. Ann. Sci. de l'Univ. de Clermont-Ferrand, Fascicule 22, n47, 240p .

De Goër De Hervé, A., Tempier, P. 1988. Notice explicative de la feuille Saint-Flour (1/50 000). BRGM ed., 92p.

Downes, H. 1984. Sr and $\mathrm{Nd}$ isotope geochemistry of coexisting alkaline magma series, Cantal, Massif Central, France. Earth and Planet. Sci. Lett. 69, 321-334.

Downes, H. 1987. Tertiary and Quaternary volcanism in the Massif Central, France. In Fitton, J.G. and Upton, B.G.J. (eds.), 1987, Alkaline Igneous Rocks, Geological Society Special Publication No. 30, 517-530.

Downes, H. 1993. The nature of the lower continental crust of Europe: petrological and geochemical evidence from xenoliths. Physics of the Earth and Planetary Interiors 79, 195 218. 
Downes, H. Dupuy, C., Leyreloup, A.F. 1990. Crustal evolution of the Hercynian belt of Western Europe: Evidence from lower-crustal granulitic xenoliths (French Massif Central). Chem. Geol. 83, 209-231.

Downes, H., Kempton, P.D., Briot, D., Harmon, R.S., Leyreloup, A.F. 1991. Pb and O isotope systematics in granulite facies xenoliths, French Massif Central: implications for crustal processes. Earth and Planet. Sci. Let. 102, 342-357.

Downes, H., Shaw, A., Williamson, B.J., Thirlwall, M.F. 1997. Hercynian granodiorites and monzogranites, Massif Central, France. Chem. Geol. 136, 99-122.

Downes, H., Reichow, M.K., Mason, P.R.D., Beard, A.D., Thirlwall, M.F. 2003. Mantle domains in the lithosphere beneath the French Massif Central: trace element and isotopic evidence from mantle clinopyroxenes. Chem. Geol. 200, 71- 87

Faure, G. 2001. Origin of igneous rocks: the isotopic evidence. Springer, 496p.

Granet, M., Wilson, M., Achauer, U. 1995. Imaging a mantle plume beneath the French Massif Central. Earth and Planet. Sci. Let. 136, 281-296.

Hamelin, C., Seitz, H.M., Barrat, J.A., Dosso, L., Maury, R.C., Chaussidon, M. 2009. A low 87Li lower crustal component: Evidence from an alkalic intraplate volcanic series (Chaîne des Puys, French Massif Central). Chem. Geol. 266, 205-217.

Hart, S.R. 1984. A large-scale isotope anomaly in the Southern Hemisphere mantle. Nature 309, 753-757.

Hart, S.R. 1988. Heterogeneous mantle domains: signatures, genesis and mixing chronologies. Earth and Planet. Sci. Let. 90, 273-296.

Hoernle, K., Zhang, Y.S., Graham, D. 1995. Seismic and geochemical evidence for large scale mantle upwelling beneath the eastern Atlantic and western and central Europe, Nature 374, 34-39. 
Jackson, M.G., Dasgupta, R. 2008. Compositions of HIMU, EM1, and EM2 from global trends between radiogenic isotopes and major elements in ocean island basalts. Earth and Planetary Science Letters 276, 175-186.

Kolb, M., Paulick, H., Kirchenbaur, M., Munker, C. 2012. Petrogenesis of mafic to felsic lavas from the Oligocene Siebengebirge volcanic field (Germany): implications for the origin of intracontinental volcanism in Central Europe. Journal of Petrology 53, 23492379.

Lenoir, X., Dautria, J.M., Briqueu, L., Cantagrel, J.M., Michard, A. 2000. Nouvelles données géochronologiques, géochimiques et isotopiques sur le volcanisme du Forez : relation avec l'évolution cénozoïque du manteau du Massif Central. C. R. Acad. Sci. 330, 201-207.

Lustrino, M., Wilson, M., 2007. The circum-Mediterranean anorogenic Cenozoic igneous province. Earth-Science Reviews 81, 1-65.

Lustrino, M., Keskin, M., Mattioli, M., Kavak, O. 2012. Heterogeneous mantle sources feeding the volcanic activity of Mt. Karacadag (SE Turkey). Journal of Asian Earth Sciences 46, 120-139.

Lustrino, M., Fedele, L., Melluso, L., Morra, V., Ronga, F., Geldmacher, J.,Duggen, S, Agostini, S., Cucciniello, C., Franciosi, L., Meisel, T. 2013. Origin and evolution of Cenozoic magmatism of Sardinia (Italy). A combined isotopic ( $\mathrm{Sr}-\mathrm{Nd}-\mathrm{Pb}-\mathrm{O}-\mathrm{Hf}-\mathrm{Os})$ and petrological view. Lithos 180-181, 138-158.

Négrel, Ph., Deschamps, P. 1996. Natural and anthropogenic budgets of a small watershed in the Massif Central (France): Chemical and strontium isotopic characterization in water and sediments. Aquat. Geochem. 2, 1-27.

Nehlig, P., Fréour, G., De Goër De Hervé, A., Huget, D., Leyrit, H., Marroncle, J.L., Roger, J., Roig, J.Y., Sumerly, F., Thieblemont, D., Vidal, N. 2001. Notice explicative de la feuille Murat (1/50 000). BRGM ed., 264p. 
Pilet, S., Hernandez, J., Sylvester, P., Poujol, M. 2005. The metasomatic alternative for ocean island basalt chemical heterogeneity. Earth and Planet. Sci. Let. 236, 148-166.

Pin, C., Bassin, C. 1992. Evaluation of a strontium-specific extraction chromatographic method for isotopic analysis in geological materials. Anal. Chim. Acta 269, 249-255.

Stettler, A., Allègre, C.J. 1979. 87Rb - 86Sr constraints on the genesis and evolution of the Cantal continental volcanic system (France). Earth and Planet. Sci. Let. 44, 269-278.

Stracke, A. 2012. Earth's heterogeneous mantle: A product of convection-driven interaction between crust and mantle. Chem. Geol. 330-331, 274-299.

Weaver, B.L. 1991. The origin of ocean island basalt end-member compositions: trace element and isotopic constraints. Earth Planet. Sci. Lett. 104, 381-397.

Willbold, M., Stracke, A. 2010. Formation of enriched mantle components by recycling of upper and lower continental crust. Chem. Geol. 276, 188-197.

Wilson, M., Downes, H. 1992. Mafic alkaline magmatism associated with the European Cenozoic rift system. Tectonophysics 208, 173-182.

Witt-Eickschen, G., Seck, H. A., Mezger, K., Eggins, S. M., Altherr, R. 2003. Lithospheric mantle evolution beneath the Eifel (Germany): constraints from $\mathrm{Sr}-\mathrm{Nd}-\mathrm{Pb}$ isotopes and trace element abundances in spinel peridotite and pyroxenite xenoliths. J. Petrol. 44, 10771095.

Zindler, A. Hart, S. 1986. Chemical geodynamics. Annual reviews of Earth Planet. Sci. 14, 493-571. 
Figure captions

Figure 1. (a) Map of the Massif Central with the location of the volcano areas (dark gray) Chaine des Puys, Cantal, Aubrac, Deves, Velay and Languedoc. The bright grey area corresponds to the extension of crystalline basement rocks of the Massif Central. (b) Local map of the Allanche river basin with bedrock sampling points. (c) Detailed geological maps of the sampling locations plotted on the 1:50,000-scale geological map from http://infoterre.brgm.fr. The three types of bedrock correspond to the labels $8 \beta \mathrm{i}$ (basanite nepheline-leucite), $8 \beta \mathrm{n}$ (basanite nepheline) and $8 \beta$ (feldspathic basalt), defined in De Goër De Hervé and Tempier (1988).

Figure 2. Plot of ${ }^{206} \mathrm{~Pb} /{ }^{204} \mathrm{~Pb},{ }^{207} \mathrm{~Pb} /{ }^{204} \mathrm{~Pb},{ }^{208} \mathrm{~Pb} /{ }^{204} \mathrm{~Pb} v$ s. the $1 / \mathrm{Pb}$ ratio $\left(\mu \mathrm{g} \cdot \mathrm{g}^{-1}\right)$ of volcanic rocks of the Massif Central including the studied Allanche river basin and data from the Chaine des Puys, the Cantal, the Forez and the Languedoc (Hamelin et al., 2009; Downes, 1984; Wilson and Downes, 1992; Pilet et al., 2005; Dautria et al., 2010). Regression line are indicated in the graph (see text) for Allanche bedrock.

Figure 3. (a) and (b) - Plot of ${ }^{87} \mathrm{Sr} /{ }^{86} \mathrm{Sr} v$ s. $1 / \mathrm{Sr}$ ratio $\left(\mu \mathrm{g} . \mathrm{g}^{-1}\right)$ of volcanic rocks of the Massif Central including the studied Allanche river basin and data from the Chaine des Puys, the Cantal, the Forez, the Velay, the Mont Dore, the Aubrac and the Languedoc (Hamelin et al., 2009; Downes, 1984; Wilson and Downes, 1992; Pilet et al., 2005; Chauvel and Jahn, 1984; Dautria et al., (2004; 2010; Condomines et al., 1982; Stettler and Allègre, 1979). Regression line and grayed area corresponding to $95 \%$ confidence. (c) and (d) - Plot of the ${ }^{87} \mathrm{Sr} /{ }^{86} \mathrm{Sr} v s$. the $\mathrm{Rb} / \mathrm{Sr}$ ratios in the volcanic rocks of the Allanche bassin compared with ratios from other rocks in the Massif Central.

Figure 4. Plot of ${ }^{208} \mathrm{~Pb} /{ }^{204} \mathrm{~Pb}$ vs. ${ }^{206} \mathrm{~Pb} /{ }^{204} \mathrm{~Pb}$ ratios of the Allanche volcanic rocks. 'NHRL' corresponds to NHRL mixing line of Hart (1984) defined for the northern hemisphere between the end-members DM and HIMU. Upper and lower crust end-members are also indicated (Variscan granitoids, meta-igneous granulites and meta-sedimentary granulites, Downes, 1993; Downes et al., 1990; 1997). Additional data are from the Chaine des Puys, the Cantal, the Forez, and the Languedoc (Hamelin et al., 2009; Downes, 1984; Wilson and Downes, 1992; Pilet et al., 2005; Dautria et al., 2010; Lenoir et al., 2000, and Briot personal 
communication; 'undifferentiated rock samples from the Massif Central volcanoes identified as Bedrock $\left.\mathrm{MC}^{\prime}\right)$.

Figure 5. Plot of ${ }^{207} \mathrm{~Pb} /{ }^{204} \mathrm{~Pb}$ vs. ${ }^{206} \mathrm{~Pb} /{ }^{204} \mathrm{~Pb}$ ratios of the Allanche volcanic rocks. Mantle endmembers are indicated (HIMU, DM, EM1, EM2, LVC, see text for details). End-members of the mantle (HIMU, DM, EM-I, EM-II, LVC) and of the upper and lower crust are indicated (Variscan granitoids, meta-igneous granulites and meta-sedimentary granulites, Downes, 1993; Downes et al., 1990; 1997). Additional data (Fig. 1) are from the Chaine des Puys, the Cantal, the Forez, and the Languedoc (Hamelin et al., 2009; Downes, 1984; Wilson and Downes, 1992; Pilet et al., 2005; Dautria et al., 2010; Lenoir et al., 2000, and Briot personal communication; 'undifferentiated rock samples from the Massif Central volcanoes identified as Bedrock MC').

Figure 6. Relationships between the $\mathrm{SiO}_{2}$ and $\mathrm{K}_{2} \mathrm{O}$ contents of the Allanche volcanic rocks. The Basanite and F-Basalt fields (for feldspathic basalts, see text) are reported. Bedrock with $\mathrm{SiO}_{2}>50 \%$ corresponds to erratic blocks in the upstream part of the Allanche catchment (Négrel and Deschamps, 1996). Data referred to as "Bedrock geological maps" are from basaltic rocks of the Cantal volcano (De Goër de Hervé and Tempier, 1988; Nehlig et al., 2001). Additional data are from volcanic rocks from the Chaine des Puys, the Cantal, the Forez, the Velay, the Mont Dore, the Aubrac and the Languedoc (Hamelin et al., 2009; Downes, 1984; Wilson and Downes, 1992; Pilet et al., 2005; Chauvel and Jahn, 1984; Dautria et al., 2004; 2010; Condomines et al., 1982; Stettler and Allègre, 1979; Lenoir et al., 2000).

Figure 7. Relationships between the $\mathrm{Sr}$ and $\mathrm{Rb}$ contents of volcanic rocks of the Massif Central; including the studied Allanche river basin and data from the Chaine des Puys, the Cantal, the Forez, the Velay, the Mont Dore, the Aubrac and the Languedoc (Hamelin et al., 2009; Downes, 1984; Wilson and Downes, 1992; Pilet et al., 2005; Chauvel and Jahn, 1984; Dautria et al., 2004; 2010; Condomines et al., 1982; Stettler and Allègre, 1979).

Figure 8. Plot of ${ }^{87} \mathrm{Sr} /{ }^{86} \mathrm{Sr} v s$. the $\mathrm{SiO}_{2}$ of volcanic rocks of the Massif Central; including the studied Allanche river basin and data the Chaine des Puys, the Cantal, the Forez, the Velay, the Mont Dore, the Aubrac and the Languedoc (Hamelin et al., 2009; Downes, 1984; Wilson and Downes, 1992; Pilet et al., 2005; Chauvel and Jahn, 1984; Dautria et al., 2004; 2010; Condomines et al., 1982; Stettler and Allègre, 1979). Dashed line and grayed area 
corresponding to the study by Kolb et al. (2012) in Germany are indicated in the graph (see text).

Figure 9. Plot of ${ }^{87} \mathrm{Sr} /{ }^{86} \mathrm{Sr}$ vs. ${ }^{206} \mathrm{~Pb} /{ }^{204} \mathrm{~Pb}$ ratios of the Allanche volcanic rocks. Mantle endmembers are indicated (HIMU, DM, EM1, EM2, LVC, see text for details). Additional data are from the Chaine des Puys, the Cantal, the Forez, and the Languedoc (Hamelin et al., 2009; Pilet et al., 2005; Dautria et al., 2010; Lenoir et al., 2000). Mixing curves involving crust, pelagic sediment, sedimentary rock and igneous granulite contaminations are illustrated.

\section{Table caption}

Table 1. Analyzed bedrock samples (feldspathic basalt, basanite (nepheline-leucite), basanite (nepheline) with ages of the corresponding volcanic cycles according to De Goër De Hervé and Tempier (1988). Lead-isotope data from bedrock expressed as ${ }^{206} \mathrm{~Pb} /{ }^{204} \mathrm{~Pb},{ }^{207} \mathrm{~Pb} /{ }^{204} \mathrm{~Pb}$ and ${ }^{208} \mathrm{~Pb} /{ }^{204} \mathrm{~Pb}$ ratios, strontium isotope data expressed as ${ }^{87} \mathrm{Sr} /{ }^{86} \mathrm{Sr}$. External reproducibility on lead-isotopic ratios is $0.1 \%(2 \sigma)$ and $\pm 10 \mathrm{ppm}\left(2 \sigma_{\mathrm{m}}\right)$ for strontium isotopic ratios. Data for major elements $\left(\mathrm{SiO}_{2}, \mathrm{~K}_{2} \mathrm{O}\right)$ and trace elements $(\mathrm{Rb}, \mathrm{Sr}$ and $\mathrm{Pb})$, are from Négrel and Deschamps (1996). 
Figure 1

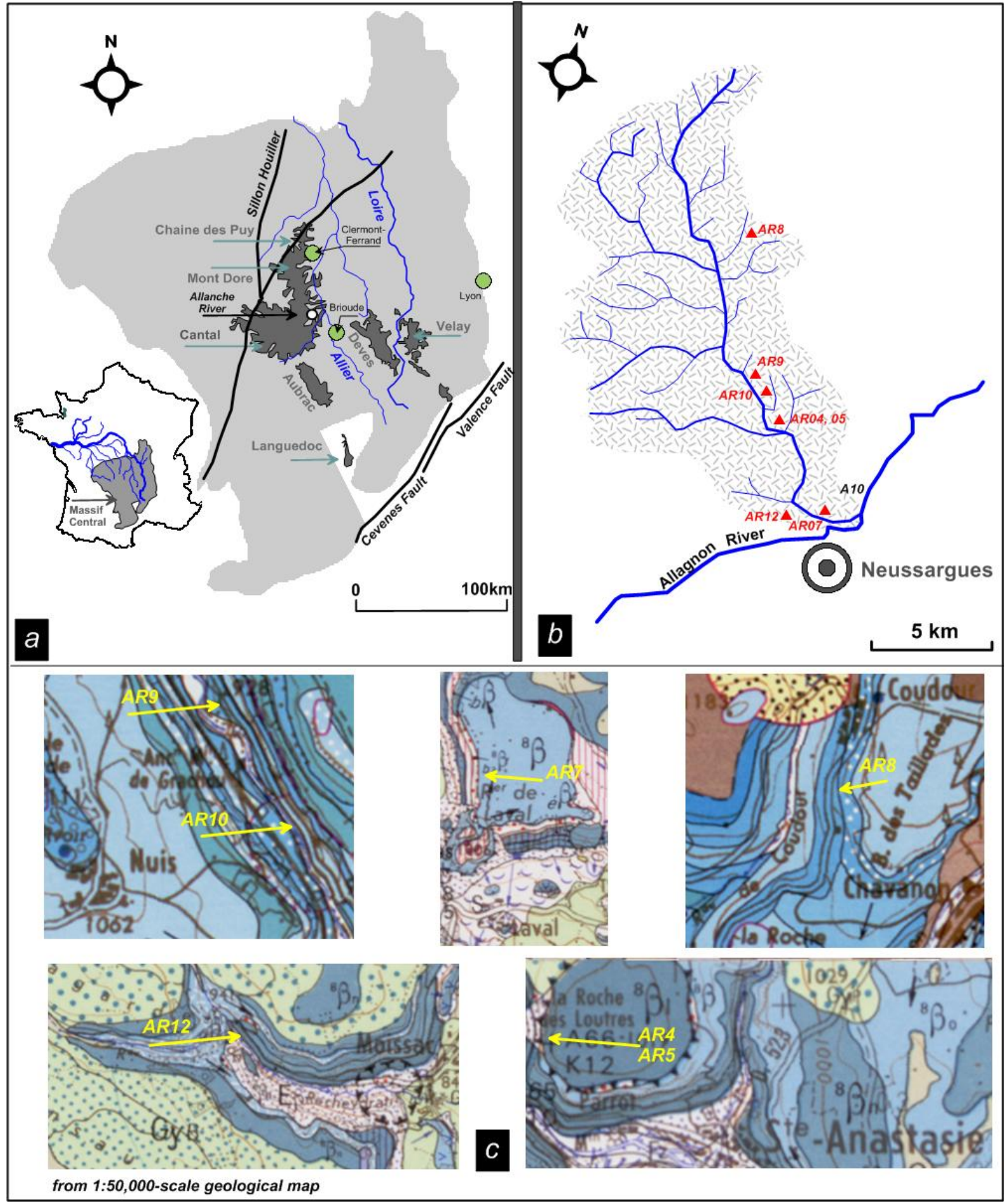


Figure 2

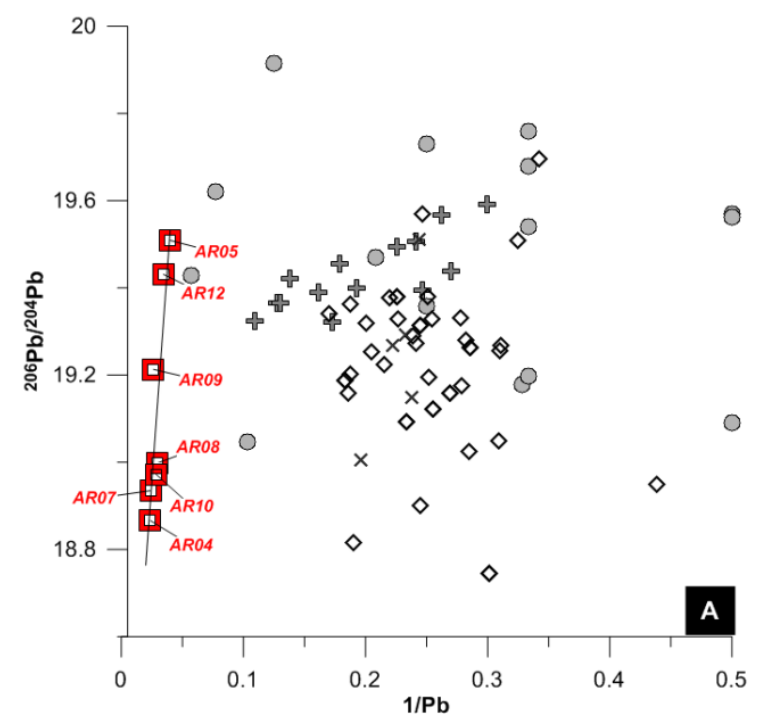

\begin{tabular}{|ll}
\hline 口 & Allanche \\
\& & Chaine des Puys \\
$\bigcirc$ & Cantal \\
$\diamond$ & Languedoc \\
$\times$ & Forez
\end{tabular}
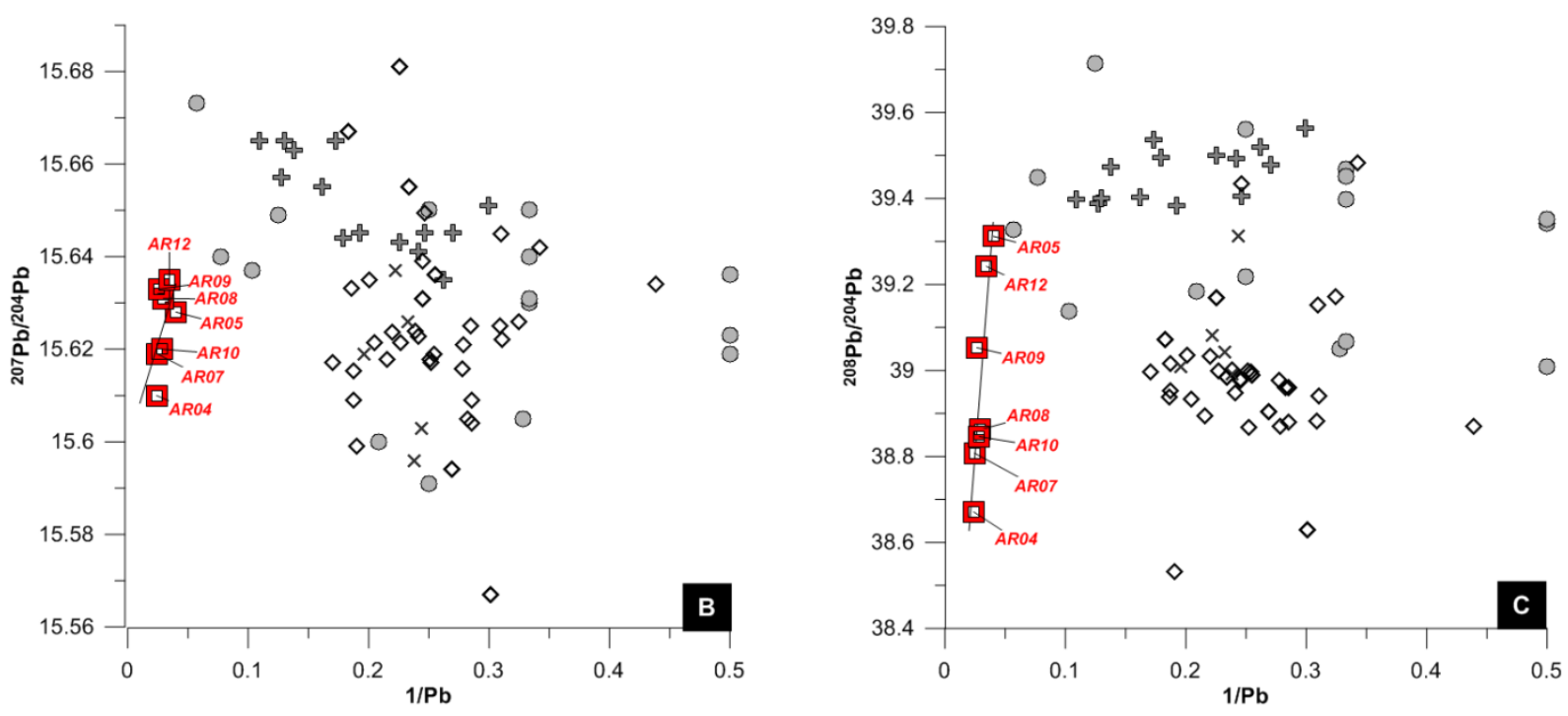
Figure 3
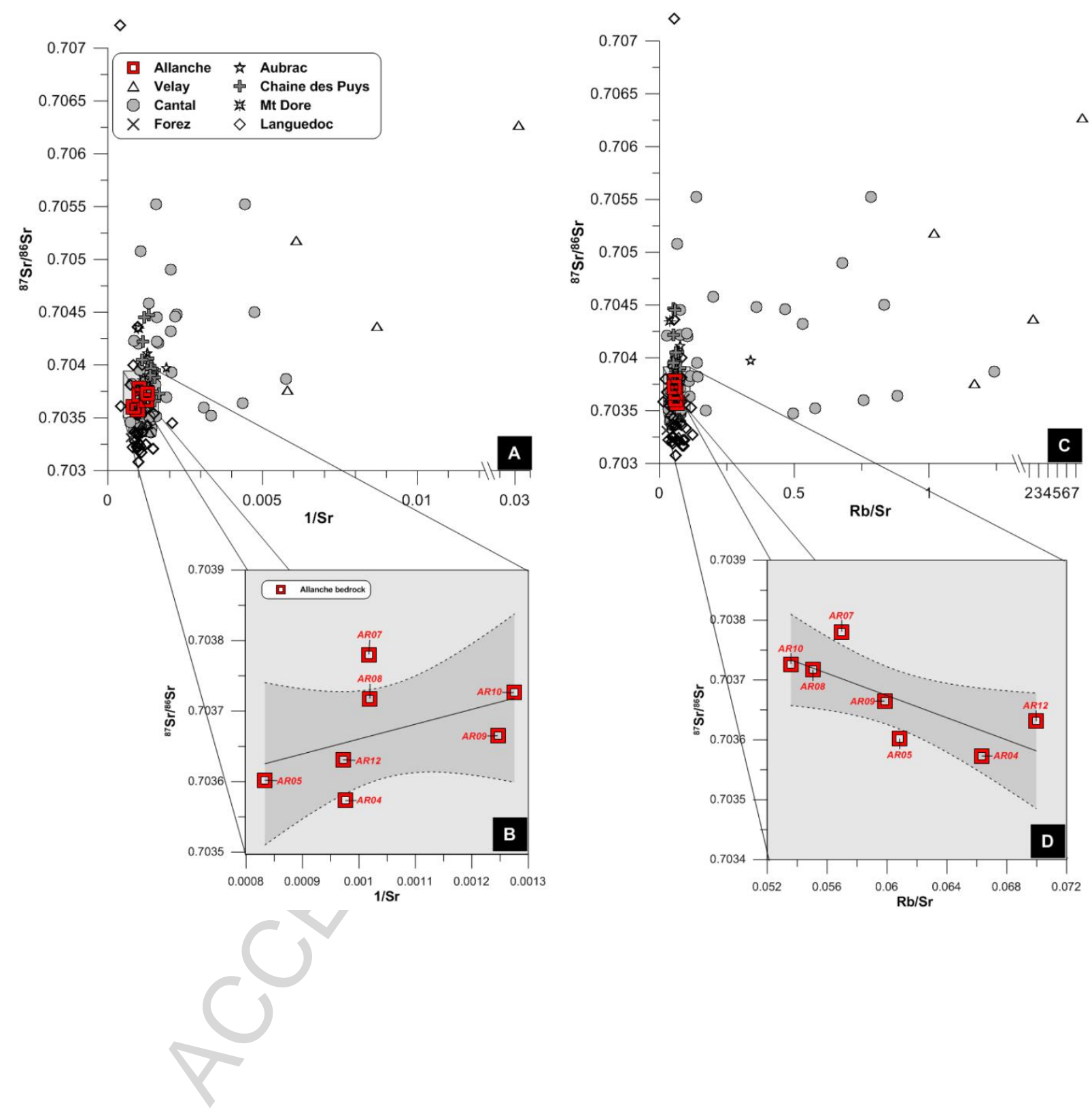
Figure 4

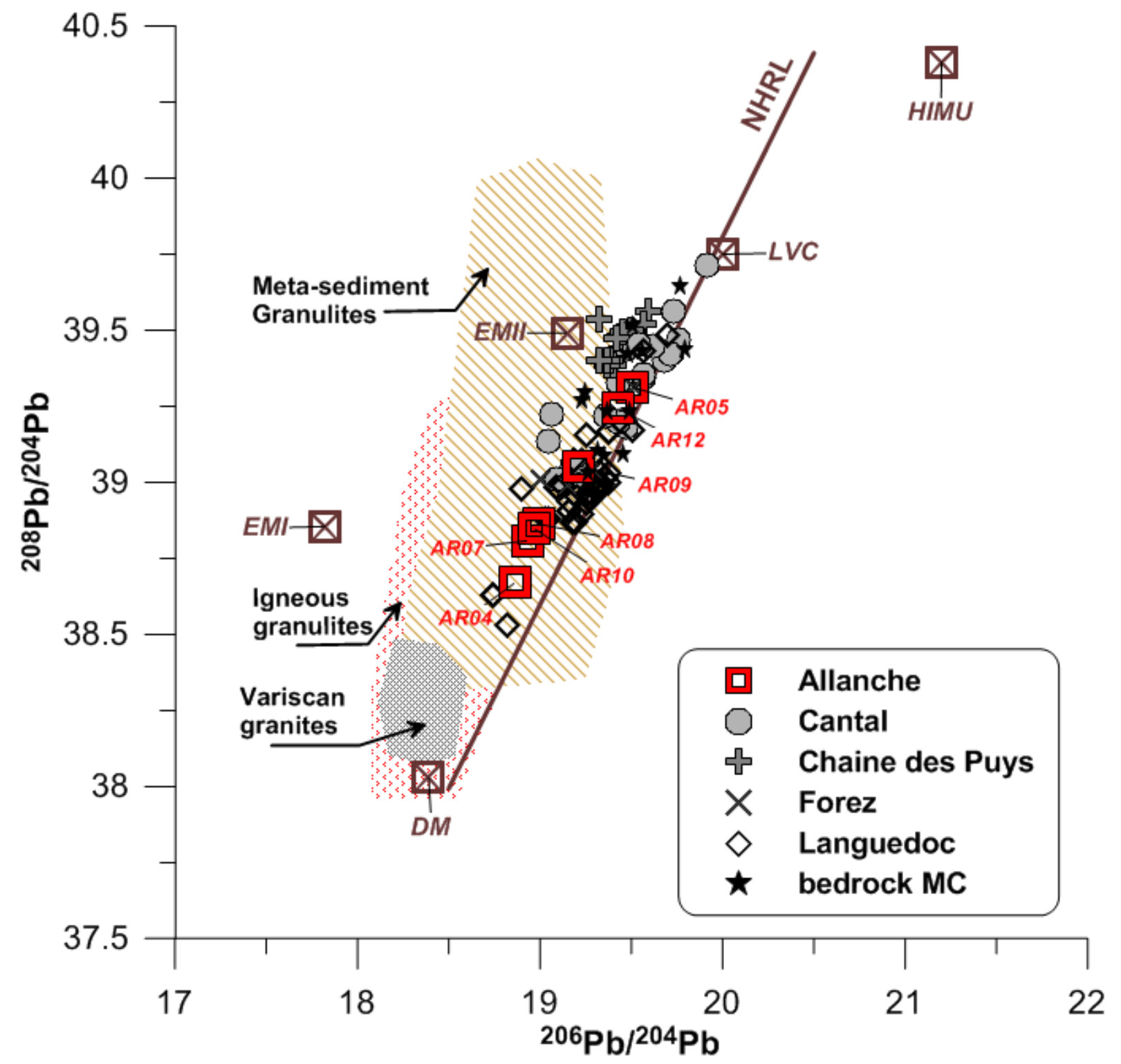


Figure 5

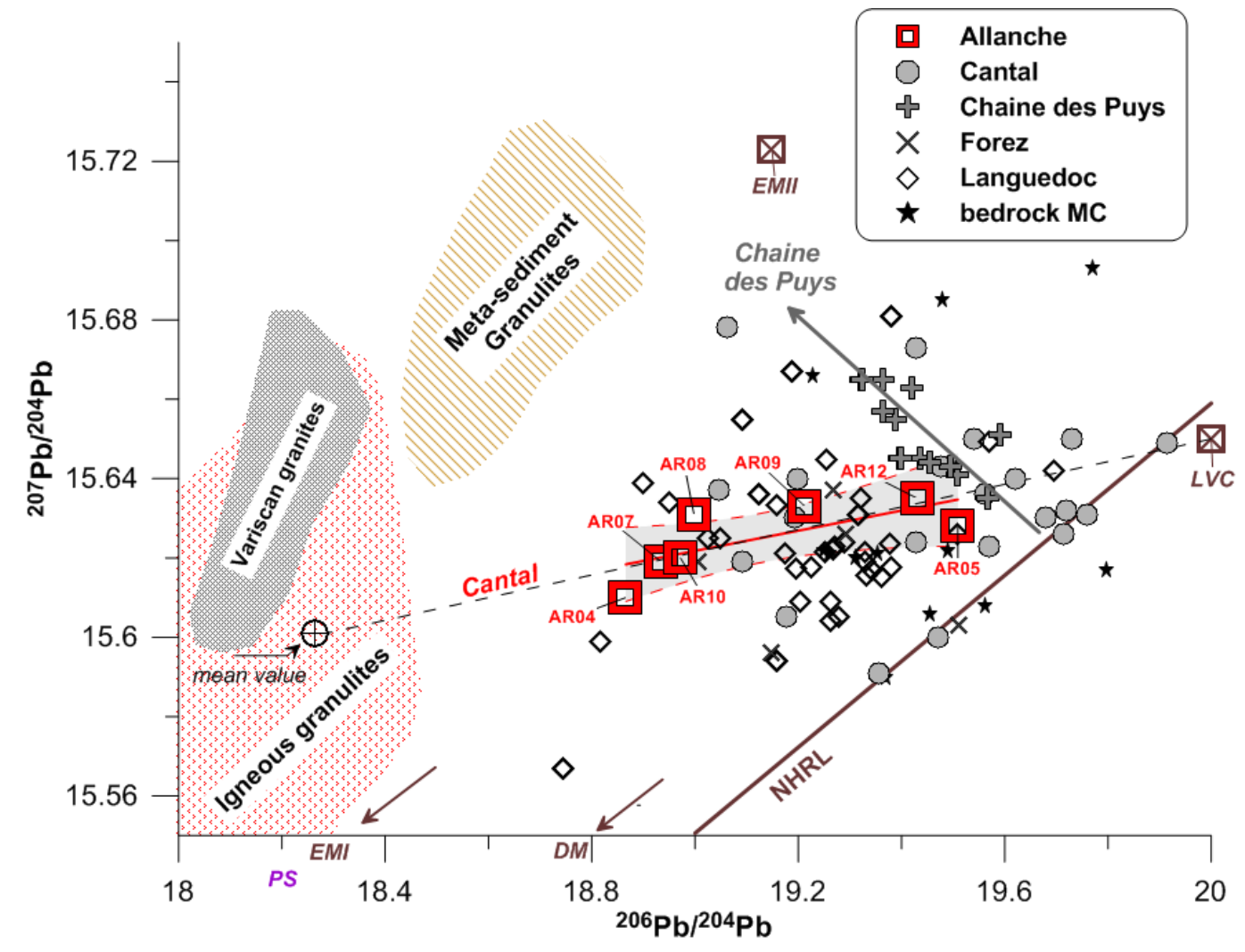


Figure 6

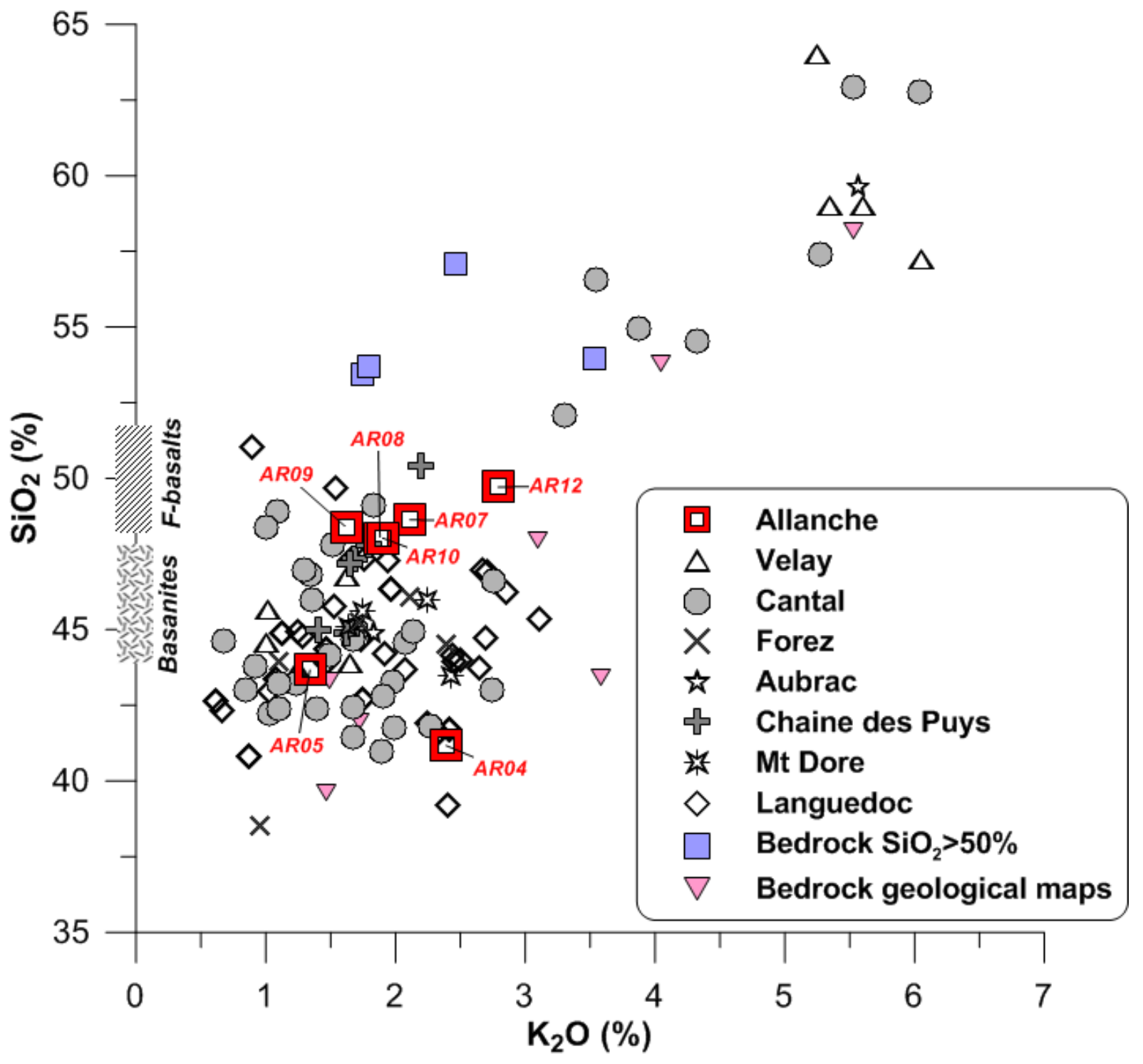


Figure 7

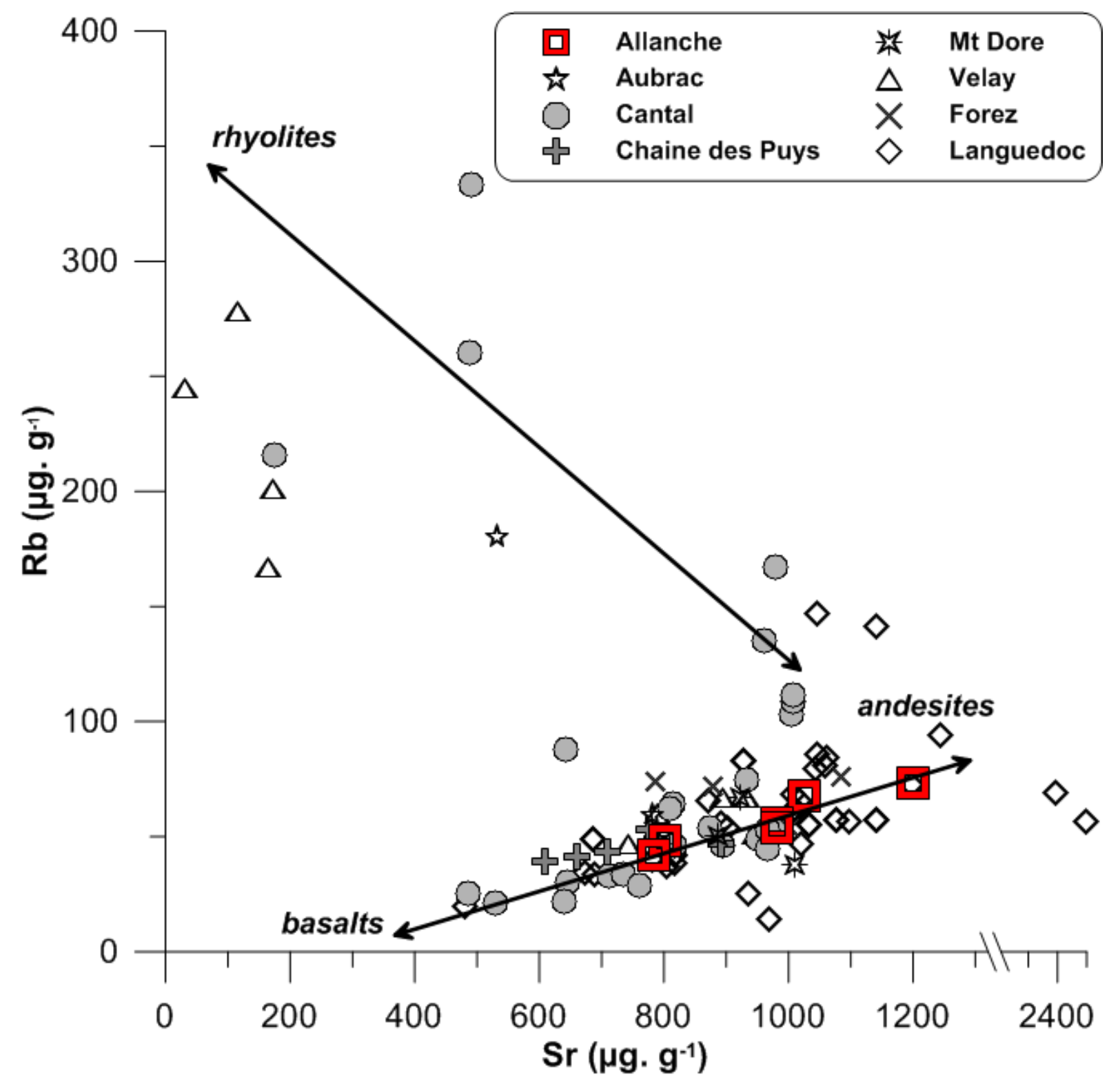


Figure 8

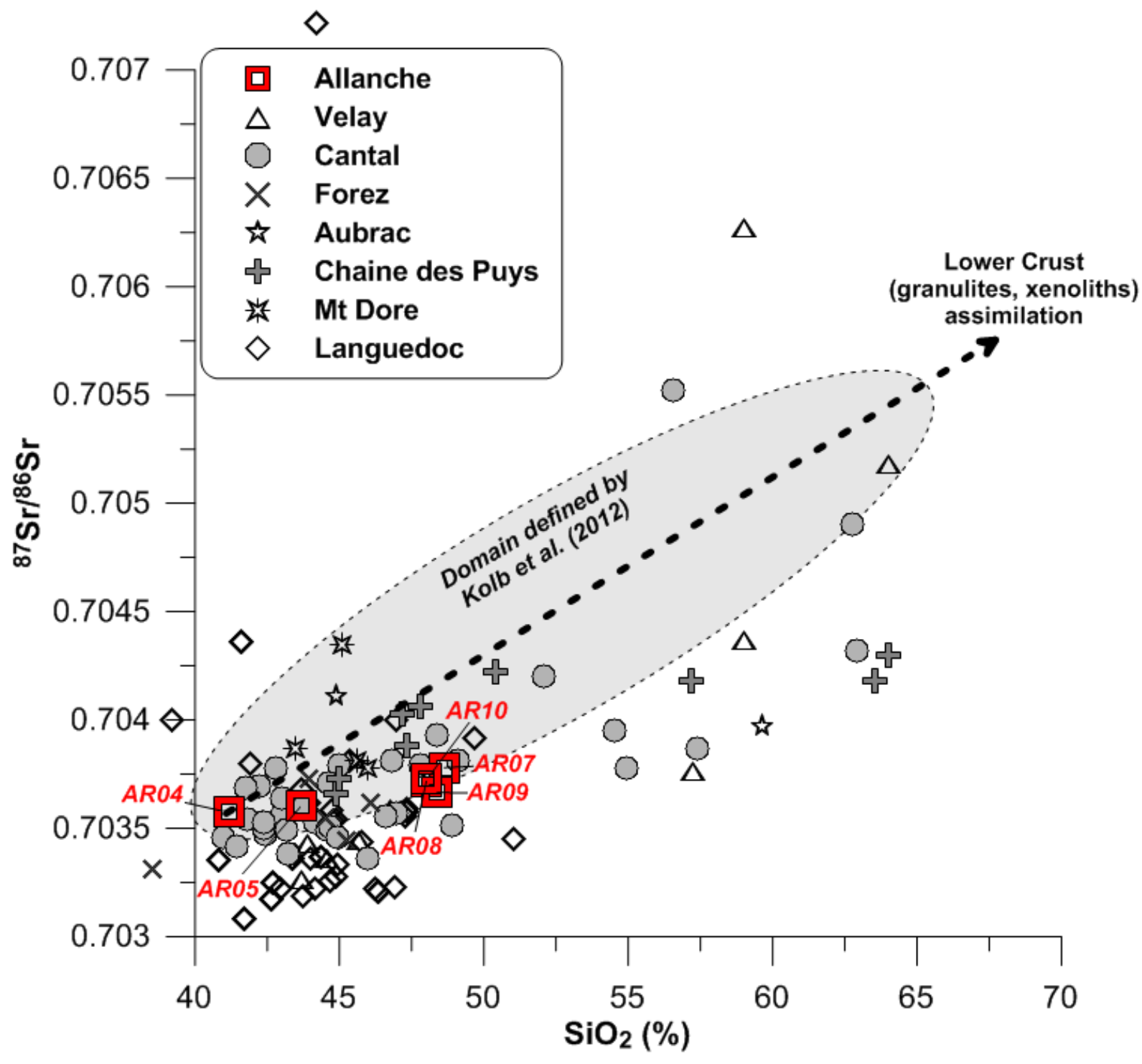


Figure 9

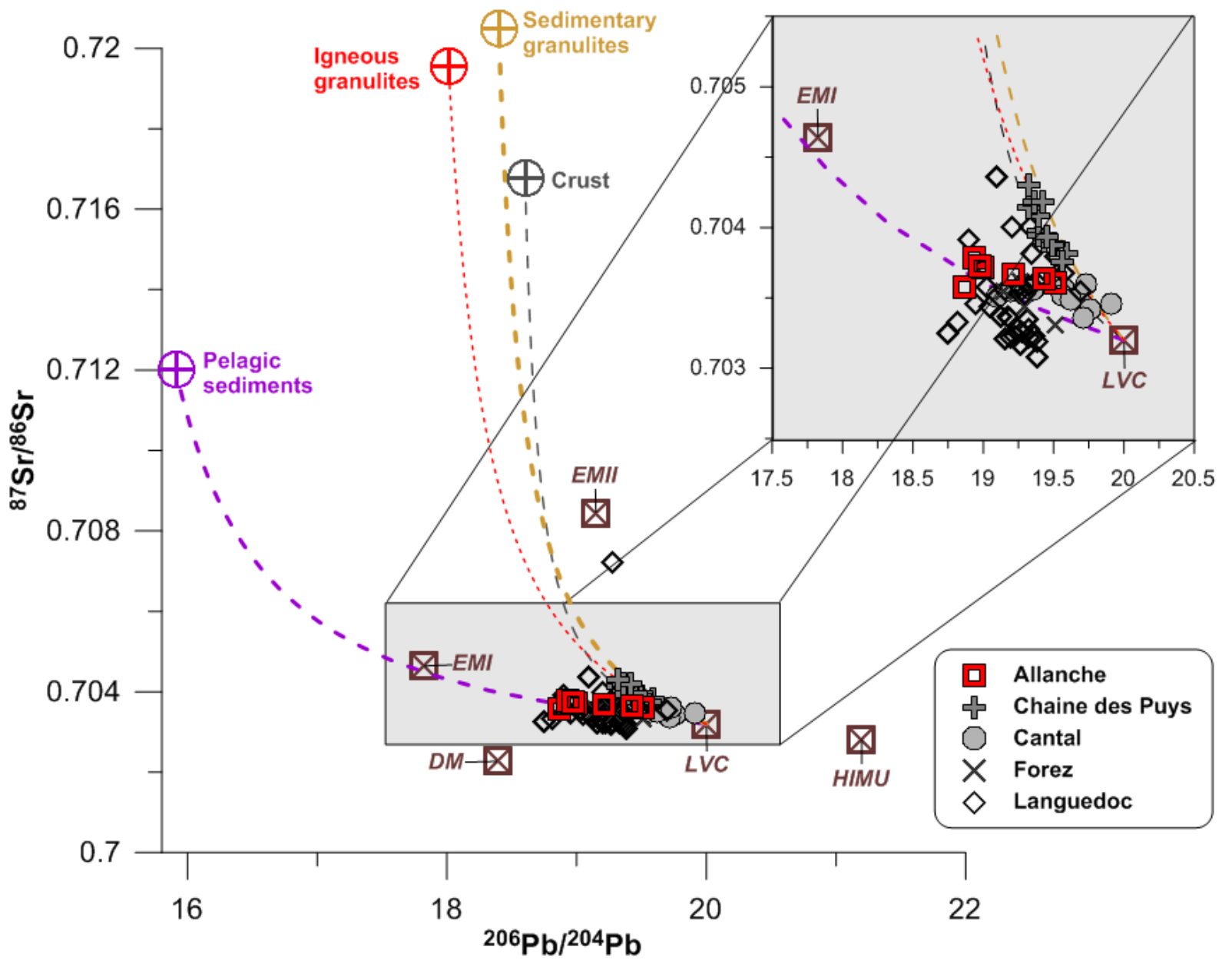


Table 1

\begin{tabular}{|c|c|c|c|c|c|c|c|c|c|c|c|c|}
\hline Name & Reference & Description & Age & ${ }^{206} \mathrm{~Pb} /{ }^{204} \mathrm{~Pb}$ & ${ }^{207} \mathrm{~Pb} /{ }^{204} \mathrm{~Pb}$ & ${ }^{208} \mathrm{~Pb} /{ }^{204} \mathrm{~Pb}$ & $\mathrm{~Pb}$ & ${ }^{87} \mathrm{Sr} /{ }^{86} \mathrm{Sr}$ & $\mathrm{Sr}$ & $\mathrm{SiO}_{2}$ & $\mathrm{~K}_{2} \mathrm{O}$ & $\mathbf{R b}$ \\
\hline & bedrock & & Ma & & & & $\mu g / g$ & & $\mu g / g$ & $\%$ & $\%$ & $\mu \mathrm{g} / \mathrm{g}$ \\
\hline Roche des Loutres & AR04 & Basanite (nepheline-leucite) & 4.2 & 18.87 & 15.61 & 38.67 & 42 & 0.703573 & 1025 & 41.17 & 2.39 & 68 \\
\hline Roche des Loutres & AR05 & Basanite (nepheline-leucite) & 4.2 & 19.51 & 15.63 & 39.31 & 25 & 0.703602 & 1200 & 43.67 & 1.34 & 73 \\
\hline Rocher de Laval & AR07 & Feldspathic basalt & 4.7 & 18.94 & 15.62 & 38.81 & 41 & 0.703780 & 983 & 48.63 & 2.11 & 56 \\
\hline Ruisseau de Coudour & AR08 & Basanite (nepheline-leucite) & 4.5 & 19.00 & 15.63 & 38.86 & 34 & 0.703717 & 981 & 48.01 & 1.88 & 54 \\
\hline Moulin de Grachou & AR09 & Basanite (nepheline) & 2.5 & 19.21 & 15.63 & 39.05 & 38 & 0.703665 & 802 & 48.38 & 1.62 & 48 \\
\hline Ancienne carrière & AR10 & Basanite (nepheline) & 2.5 & 18.97 & 15.62 & 38.85 & 35 & 0.703726 & 784 & 48.03 & 1.90 & 42 \\
\hline Cotes d'Auzolle & AR12 & Basanite (nepheline) & 2.5 & 19.43 & 15.64 & 39.24 & 29 & 0.703631 & 1029 & 49.71 & 2.79 & 72 \\
\hline mean & & & & & & & 34.9 & & 972.0 & 46.8 & 2.0 & 59.0 \\
\hline standard deviation & & & & & & & 5.7 & & 132.3 & 2.9 & 0.4 & 11.3 \\
\hline variation & & & & & & & $16 \%$ & & $14 \%$ & $6 \%$ & $22 \%$ & $19 \%$ \\
\hline
\end{tabular}




\section{Highlights}

Lead and strontium isotopes were studied in volcanic rocks

A large area of Tertiary to recent continental alkaline volcanism in the Massif Central (France) was investigated

a complex history and multiple reservoir sources and mixing is confirmed

Cross plot of $\mathrm{Sr}$ vs. $\mathrm{Pb}$ isotopes reveals a mixing between low-velocity component LVC and EMI-pelagic sediments end-members 